Article

\title{
Imaging Hydrogen Sulfide in Hypoxic Tissue with $\left[{ }^{99 m}\right.$ Tc]Tc-Gluconate
}

\author{
Yongkyoung Kweon ${ }^{1,2}$, Ji-Yong Park ${ }^{1,2}$, Young-Joo Kim ${ }^{1}$, Yun-Sang Lee ${ }^{1} \mathbb{D}$ and Jae-Min Jeong ${ }^{1,2,3, * \mathbb{D}}$ \\ 1 Department of Nuclear Medicine, Seoul National University College of Medicine, Seoul 03080, Korea; \\ kweon605@gmail.com (Y.K.); pjypoo@hanmail.net (J.-Y.P.); yjukim@snu.ac.kr (Y.-J.K.); \\ wonza43@snu.ac.kr (Y.-S.L.) \\ 2 Department of Biomedical Sciences, Seoul National University College of Medicine, Seoul 03080, Korea \\ 3 Department of Nuclear Medicine, Cancer Research Institute, Seoul National University, Seoul 03080, Korea \\ * Correspondence: jming@snu.ac.kr; Tel.: +82-2-2072-3805
}

Citation: Kweon, Y.; Park, J.-Y.; Kim, Y.-J.; Lee, Y.-S.; Jeong, J.-M. Imaging Hydrogen Sulfide in Hypoxic Tissue

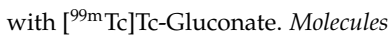
2021, 26, 96. https://doi.org/ $10.3390 /$ molecules 26010096

Academic Editor: Cristina Bolzati Received: 27 November 2020 Accepted: 23 December 2020 Published: 28 December 2020

Publisher's Note: MDPI stays neutral with regard to jurisdictional claims in published maps and institutional affiliations.

Copyright: (C) 2020 by the authors. Licensee MDPI, Basel, Switzerland. This article is an open access article distributed under the terms and conditions of the Creative Commons Attribution (CC BY) license (https: / / creativecommons.org/ licenses/by/4.0/).

\begin{abstract}
Hydrogen sulfide $\left(\mathrm{H}_{2} \mathrm{~S}\right)$ is the third gasotransmitter and is generated endogenously in hypoxic or inflammatory tissues and various cancers. We have recently demonstrated that endogenous $\mathrm{H}_{2} \mathrm{~S}$ can be imaged with [ ${ }^{99 \mathrm{~m}} \mathrm{Tc}$ ]Tc-gluconate. In the present study, we detected $\mathrm{H}_{2} \mathrm{~S}$ generated in hypoxic tissue, both in vitro and in vivo, using [ [99m Tc]Tc-gluconate. In vitro uptake of $\left[{ }^{99 \mathrm{~m}} \mathrm{Tc}\right] \mathrm{Tc}$-gluconate was measured under hypoxic and normoxic conditions, using the colon carcinoma cell line CT26, and was higher in hypoxic cells than that in normoxic cells. An acute hindlimb ischemia-reperfusion model was established in BALB/c mice by exposing the animals to $3 \mathrm{~h}$ of ischemia and $3 \mathrm{~h}$ of reperfusion prior to in vivo imaging. [ ${ }^{99 \mathrm{~m}} \mathrm{Tc}$ ] Tc-gluconate $(12.5 \mathrm{MBq})$ was intravenously injected through the tail vein, and uptake in the lower limb was analyzed by singlephoton emission computed tomography/computed tomography (SPECT/CT). SPECT/CT images showed five times higher uptake in the ischemic limb than that in the normal limb. The standard uptake value (SUVmean) of the ischemic limb was $0.39 \pm 0.03$, while that of the normal limb was $0.07 \pm 0.01$. [ $\left.{ }^{99 \mathrm{~m}} \mathrm{Tc}\right] \mathrm{Tc}$-gluconate is a novel imaging agent that can be used both in vitro and in vivo for the detection of endogenous $\mathrm{H}_{2} \mathrm{~S}$ generated in hypoxic tissue.
\end{abstract}

Keywords: $\mathrm{H}_{2} \mathrm{~S}$; technetium-99m; hypoxia; gluconate

\section{Introduction}

Gasotransmitters are small signaling molecules that can freely permeate through membranes [1]. Gaseous signaling molecules are either synthesized endogenously in an organ, tissue, or cell, or are received from outside, and the production can be induced by certain physiological or biochemical changes [2]. Gasotransmitters are a subfamily of endogenous gas molecules, including nitrogen oxide (NO), carbon monoxide (CO), and hydrogen sulfide $\left(\mathrm{H}_{2} \mathrm{~S}\right)$, which is the most recently identified gasotransmitter [3]. $\mathrm{H}_{2} \mathrm{~S}$ plays an important role in various physiological processes, such as regulation of inflammation, vasodilation, oxygen sensing, angiogenesis, hypoxia, and reperfusion injury [4].

$\mathrm{H}_{2} \mathrm{~S}$ can easily be oxidized to sulfur-containing substances, such as hydrogen sulfide $\left(\mathrm{HS}^{-}\right)$and sulfide $\left(\mathrm{S}^{2-}\right)$ in aqueous solution [5]. Dynamic equilibrium in the sequential reactions is achieved as follows:

$$
\mathrm{H}_{2} \mathrm{~S} \rightleftharpoons \mathrm{HS}^{-}+\mathrm{H}^{+} \rightleftharpoons \mathrm{S}^{2-}+2 \mathrm{H}^{+}
$$

Approximately $20 \%$ of the $\mathrm{H}_{2} \mathrm{~S}$ content exists in an undissociated form, and the rest is dissociated as $\mathrm{HS}^{-}$and $\mathrm{H}^{+}$under physiological conditions of $\mathrm{pH} 7.4$ and a temperature of $37^{\circ} \mathrm{C}$. $\mathrm{HS}^{-}$can dissociate further into $\mathrm{H}^{+}$and sulfide ions $\left(\mathrm{S}^{2-}\right)$ at alkaline $\mathrm{pH}$. Therefore, $S^{2-}$ is not found in significant quantities in vivo. However, there is no exact ratio for the level of individual components of all three molecules of sulfide. $\mathrm{H}_{2} \mathrm{~S}$ can be 
produced endogenously in mammalian tissues through both non-enzymatic and enzymatic pathways $[2,5,6]$. The nonenzymatic pathway occurs when cysteine thiols interact with $\mathrm{H}_{2} \mathrm{~S}$ to form stable persulfides at $\mathrm{pH} 8.4$ [6]. To date, the contribution of the nonenzymatic pathway to the overall $\mathrm{H}_{2} \mathrm{~S}$ production inside the cells remains unclear. For the enzymatic pathway, there are three main enzymes, namely, cystathionine $\beta$-synthase (CBS), cystathionine $\gamma$-lyase (CSE), and 3-mercaptopyruvate sulfurtransferase (3-MST) [7].

Recent research has demonstrated that the CSE protein is localized in the cytosol under normal conditions, but translocates into the mitochondria under hypoxic conditions, where it metabolizes L-cysteine to produce $\mathrm{H}_{2} \mathrm{~S}[7,8]$. Production of $\mathrm{H}_{2} \mathrm{~S}$ is regulated by changes in the partial pressure of oxygen, which increases under hypoxic conditions [8]. $\mathrm{H}_{2} \mathrm{~S}$ also interacts with different membrane ion channels to regulate the vascular smooth muscle [9]. Increased $\mathrm{H}_{2} \mathrm{~S}$ levels may cause pre-constricted blood vessels to expand, thereby increasing the supply of oxygen under oxygen-deprived conditions [10].

Common methods of detecting $\mathrm{H}_{2} \mathrm{~S}$ include the use of methylene blue assay, ionselective electrodes, amperometric sensors, or gas chromatography [11]. Although no adequate quantification method has been developed to detect $\mathrm{H}_{2} \mathrm{~S}$ inside intact living organisms [12], there are several reports of in vivo imaging of $\mathrm{H}_{2} \mathrm{~S}$ using fluorescence and luminescence. However, fluorescence probes lack sensitivity and depth penetration, due to background autofluorescence and light scattering [13]. Therefore, in the present study we used radionuclides for imaging of endogenously produced $\mathrm{H}_{2} \mathrm{~S}$.

Single-photon emission computed tomography (SPECT) is an in vivo imaging modality. When a radiotracer emitting gamma-ray is injected into the body, it can be measured directly by SPECT cameras [14]. Although there are many radioisotopes available for in vivo imaging, technetium-99m is the most commonly used isotope for diagnostic purposes [15]. ${ }^{99 \mathrm{~m}} \mathrm{Tc}$ has a short half-life of $6 \mathrm{~h}$ and is inexpensive and available in many hospitals. It can be obtained conveniently from ${ }^{99} \mathrm{Mo} /{ }^{99 \mathrm{~m}} \mathrm{Tc}$ generators. The use of a ${ }^{99 \mathrm{~m}}$ Tc-labeled agent for diagnosis of hypoxia is therefore practical in the clinical setting.

The first reported radionuclide for imaging $\mathrm{H}_{2} \mathrm{~S}$ was a ${ }^{64} \mathrm{Cu}$-labeled cyclen, which was imaged using positron emission tomography (PET) [16]. However, ${ }^{64} \mathrm{Cu}$ is only available in limited institutions that have expensive cyclotrons, and the production cost of ${ }^{64} \mathrm{Cu}$ is high. Recently, we developed ${ }^{99}$ Tc-labeled agents for the quantification of $\mathrm{H}_{2} \mathrm{~S}$ in vivo [17]. Various $\alpha$-hydroxy acids such as D-gluconic acid, D-glucaric acid, and glucoheptonic acid, can be labeled with ${ }^{99 \mathrm{~m}}$ Tc. These ${ }^{99 \mathrm{~m}}$ Tc-labeled agents form an insoluble fraction in the presence of $\mathrm{H}_{2} \mathrm{~S}$, which enables imaging of endogenously produced $\mathrm{H}_{2} \mathrm{~S}$.

In the present study, we evaluated [ $\left.{ }^{99 \mathrm{~m}} \mathrm{Tc}\right] \mathrm{Tc}$-gluconate for imaging of $\mathrm{H}_{2} \mathrm{~S}$ under hypoxic conditions, since it showed the highest percentage of insoluble fraction formation with $\mathrm{H}_{2} \mathrm{~S}$. We also compared the results of in vivo imaging of endogenously produced $\mathrm{H}_{2} \mathrm{~S}$ using a fluorescent probe with imaging using [ $\left.{ }^{99 \mathrm{~m}} \mathrm{Tc}\right] \mathrm{Tc}-$ gluconate.

\section{Results}

\section{1. ${ }^{99 m}$ Tc-Labeling of Gluconate and Diethylenetriaminepentaacetic Acid (DTPA)}

Stannous chloride was used as a reducing agent for the labeling of gluconate and DTPA with ${ }^{99 m}$ Tc. Both reagents demonstrated near quantitative labeling yield $(99.8 \% \pm 0.1 \%$, 399.2 MBq).

\subsection{Formation of Insoluble Fraction with the Presence of $\mathrm{H}_{2} \mathrm{~S}$}

NaHS solution was used instead of $\mathrm{H}_{2} \mathrm{~S}$ gas for convenience, as it generates $\mathrm{H}_{2} \mathrm{~S}$ in an aqueous solution. [ ${ }^{99 \mathrm{~m}} \mathrm{Tc}$ ] Tc-Gluconate and [ ${ }^{99 \mathrm{~m}} \mathrm{Tc}$ ] Tc-DTPA were incubated with $0.1 \mathrm{mM}$ NaHS in $0.1 \mathrm{M}$ phosphate buffer ( $\mathrm{pH} \mathrm{7.4)}$ for $10 \mathrm{~min}$ at $37^{\circ} \mathrm{C}$. The reactants were analyzed using instant thin layer chromatography (ITLC)/saline. [ ${ }^{99 \mathrm{~m}} \mathrm{Tc}$ ] Tc-Gluconate formed an insoluble fraction $(88.9 \% \pm 2.4 \%)$ in the presence of $\mathrm{H}_{2} \mathrm{~S}$; however, [ $\left.{ }^{99 \mathrm{~m}} \mathrm{Tc}\right] \mathrm{Tc}-\mathrm{DTPA}$ did not form an insoluble fraction (Figure 1). 

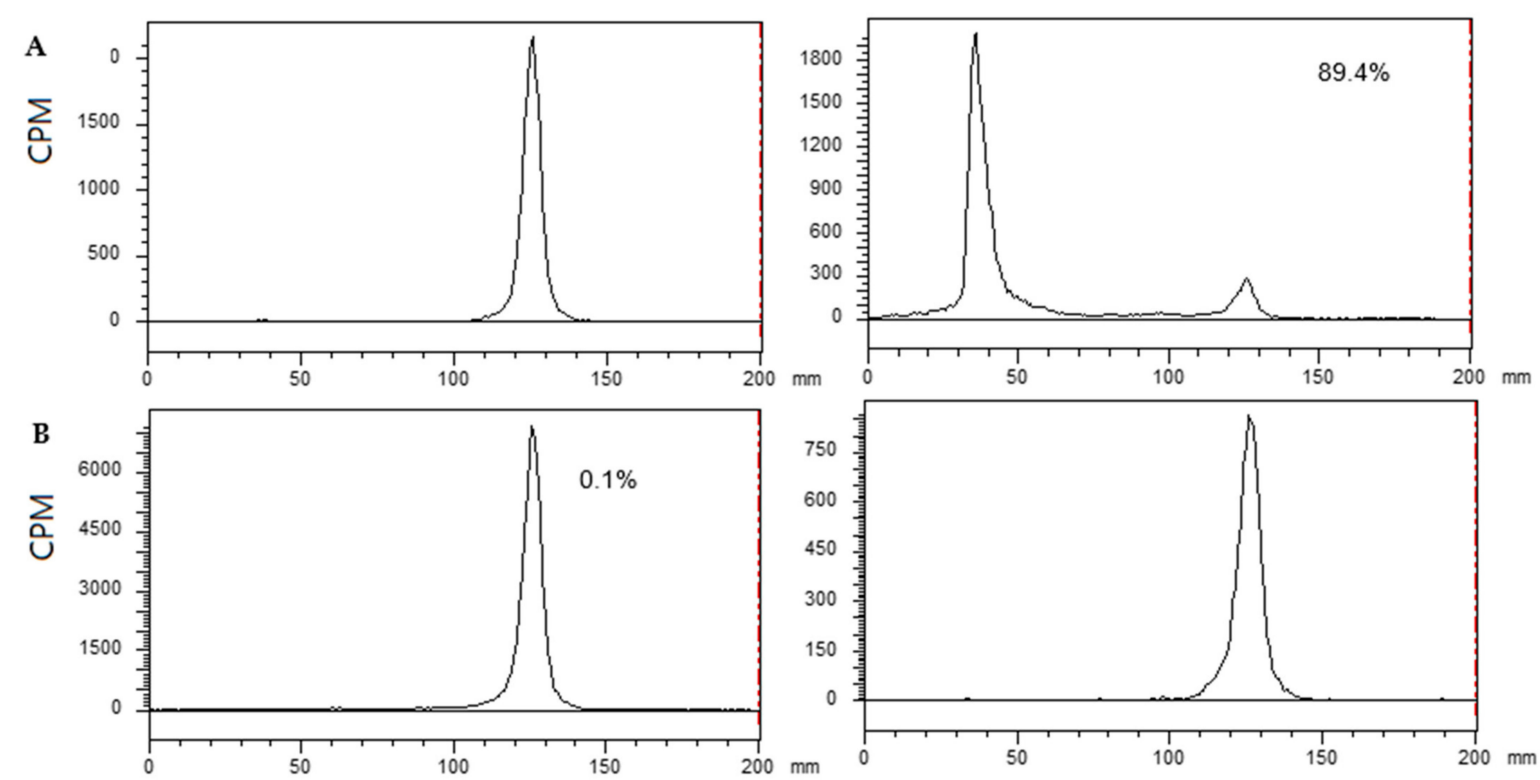

Figure 1. Comparison of insoluble fraction formation. Instant thin layer chromatography-silica gel (ITLC-SG) data eluted with saline. ${ }^{99 \mathrm{~m}} \mathrm{Tc}-$ labeled agents were subjected to reaction with $\mathrm{NaHS}$ at $37^{\circ} \mathrm{C}$ for $10 \mathrm{~min}$ at $\mathrm{pH} 7.4$. The radioactivity remaining at the origin was calculated as the insoluble fraction. (A) [ $\left.{ }^{99 \mathrm{~m}} \mathrm{Tc}\right] \mathrm{Tc}-$ Gluconate (left: before reaction; right: after reaction) and $(\mathbf{B})\left[{ }^{99 \mathrm{~m}} \mathrm{Tc}\right] \mathrm{Tc}-\mathrm{DTPA}$ (left: before reaction; right: after reaction).

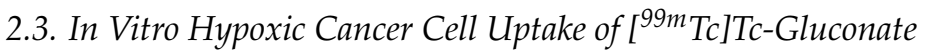

Cell uptake measurements of $\left[{ }^{99 \mathrm{~m}} \mathrm{Tc}\right] \mathrm{Tc}-$ gluconate and $\left[{ }^{99 \mathrm{~m}} \mathrm{Tc}\right] \mathrm{Tc}-\mathrm{DTPA}$ as the control were performed in a hypoxia- and normoxia-conditioned colon carcinoma cell line, CT26, for up to $2 \mathrm{~h}$. The radioactivity of the sample, indicated as counts per minute (CPM), was divided by the total protein amount and expressed as mean \pm SD for triplicate measurements. At $120 \mathrm{~min}$ of incubation, $\left[{ }^{99 \mathrm{~m}} \mathrm{Tc}\right] \mathrm{Tc}-$ gluconate uptake in hypoxic and normoxic CT26 cells increased 109,772.48 \pm 6889.49 and 25,588.32 $\pm 1886.07 \mathrm{CPM} / \mathrm{mg}$, respectively (Figure 2). In contrast, $\left[{ }^{99 \mathrm{~m}} \mathrm{Tc}\right] \mathrm{Tc}-\mathrm{DTPA}$ uptake only reached $5198.67 \pm 466.80$ and $4770.28 \pm 167.79 \mathrm{CPM} / \mathrm{mg}$, respectively, at $120 \mathrm{~min}$ (Figure 2). [99m Tc]Tc-Gluconate demonstrated significantly increased uptake in hypoxia-conditioned cancer cells, and slightly increased uptake in normoxic cancer cells. However, the control did not show any increased uptake both in hypoxic and normoxic cancer cells.

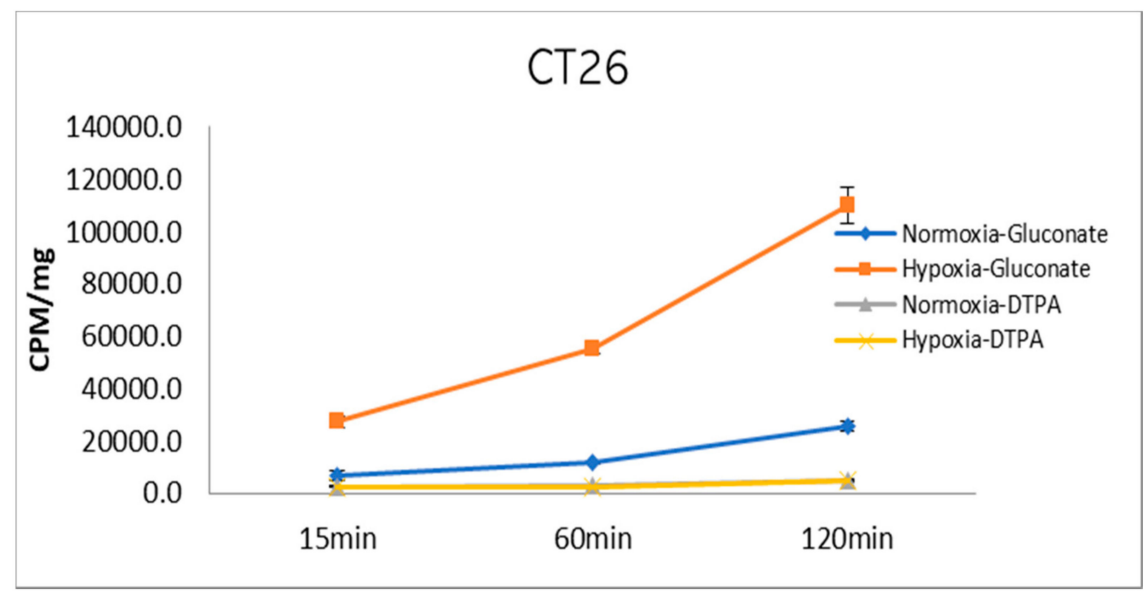

Figure 2. In vitro uptake of [ $\left.{ }^{99 \mathrm{~m}} \mathrm{Tc}\right] \mathrm{Tc}$-gluconate and [ $\left.{ }^{99 \mathrm{~m}} \mathrm{Tc}\right] \mathrm{Tc}-\mathrm{DTPA}$. Cell uptake was measured under hypoxic and normoxic conditions. Cells were harvested at 15,60, and $120 \mathrm{~min}$, and the radioactivity was measured using a gamma counter. The value was expressed as CPM/mg of the total cellular protein. $(n=3)$. 


\subsection{In Vivo Detection of Endogenous $\mathrm{H}_{2} \mathrm{~S}$ Using a Fluorescence Probe in a Mouse Model}

To compare the $\mathrm{H}_{2} \mathrm{~S}$ production in normal and ischemic hind limbs, an $\mathrm{H}_{2} \mathrm{~S}$-detecting fluorescence probe (HSip-1) was injected intravenously at different time points during reperfusion. The highest fluorescence intensity in the ischemic limbs was detected after $3 \mathrm{~h}$ of reperfusion, which indicated that $\mathrm{H}_{2} \mathrm{~S}$ production was highest at $3 \mathrm{~h}$ after reperfusion. The $\mathrm{H}_{2} \mathrm{~S}$ detection probe (HSip-1) mainly accumulated in the ischemic leg, while a relatively less intense fluorescence signal was observed in the normal leg (Figure 3). The signal decreased as the reperfusion time increased beyond $3 \mathrm{~h}$. At $24 \mathrm{~h}$ of reperfusion, fluorescence intensities were almost the same in both the normal and ischemic legs (Figure 3).

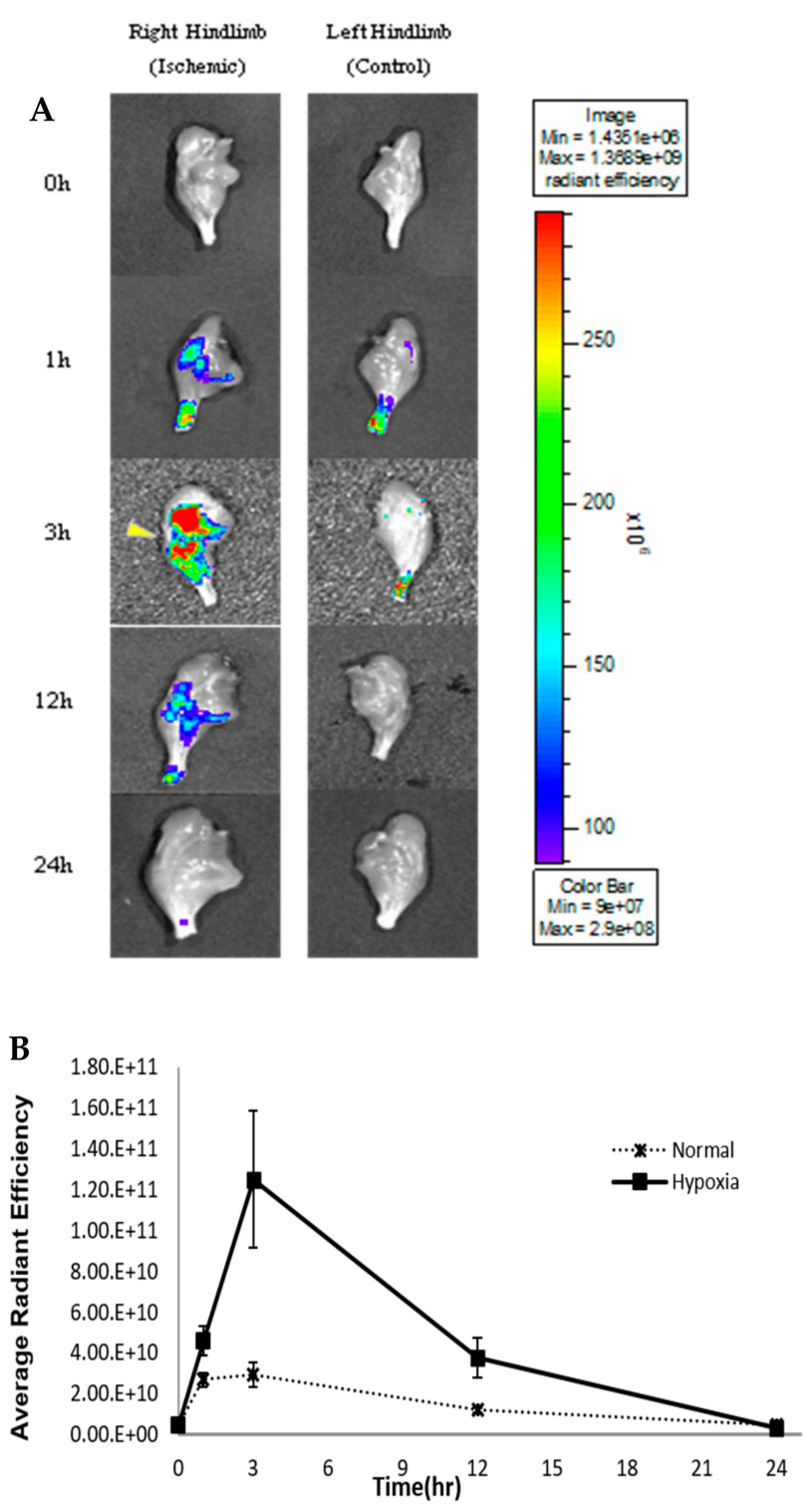

Figure 3. In vivo fluorescence imaging of endogenous $\mathrm{H}_{2} \mathrm{~S}$ by fluorescence probe in a rat model. (A) Fluorescence images (Lumina II) at the following time points: 0, 1, 3, 12 and $24 \mathrm{~h}$. Left legs show normal and right legs show hypoxic conditions $(n=4)$. Yellow triangle represents hypoxic region. (B) Fluorescence intensity of both normal and ischemic regions across $24 \mathrm{~h}$.

Immunofluorescence staining and confocal imaging were performed with hindlimb sections after $3 \mathrm{~h}$ of reperfusion. The fluorescence intensities of EF5 (hypoxia detection) and HSip- $1\left(\mathrm{H}_{2} \mathrm{~S}\right.$ detection $)$ in the ischemic leg tissue were higher than those in the normal leg tissue (Figure 4). 
A
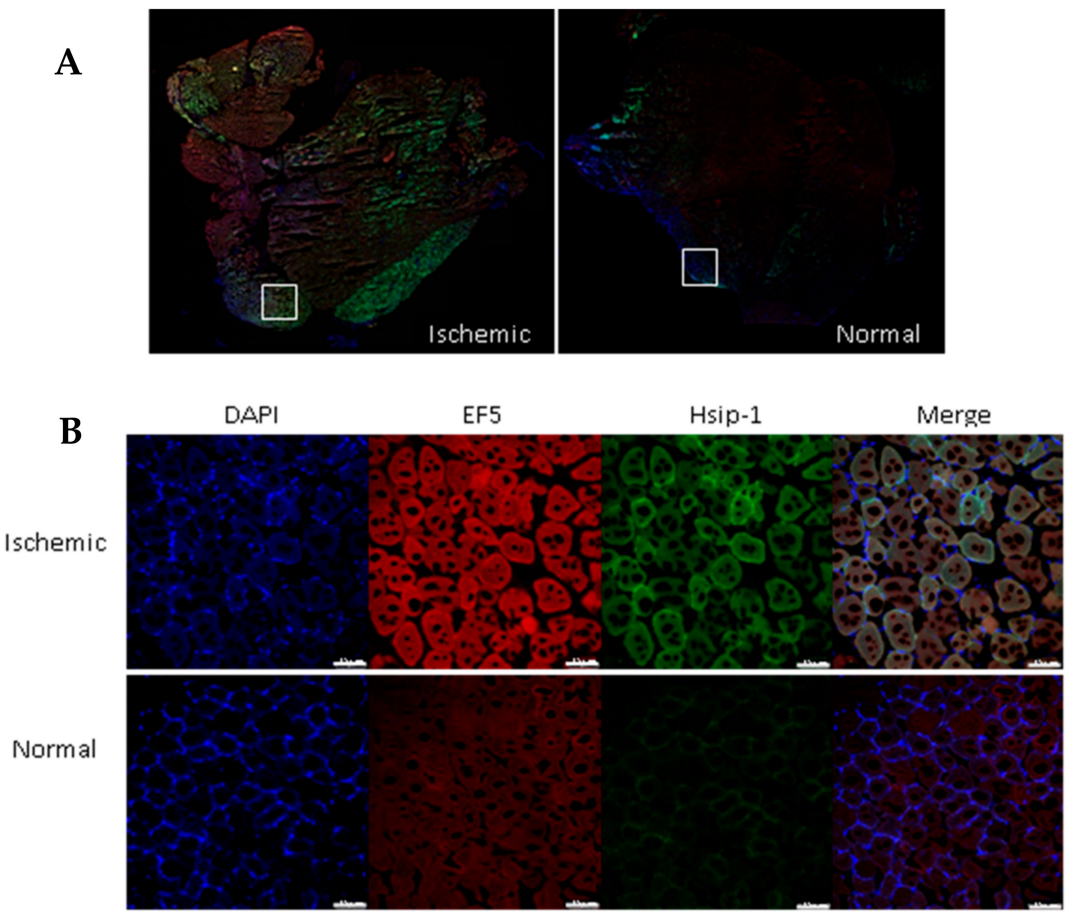

Figure 4. Immunofluorescence staining of hindlimb sections. (A) Fluorescence images of ischemic and normal tissue. Tissue imaging was performed with a confocal microscope. Original magnification: $100 \times$. (B) Red indicates EF5 (hypoxia detection), green indicates HSip-1 $\left(\mathrm{H}_{2} \mathrm{~S}\right.$ detection), and blue indicates DAPI (nuclei). Original magnification: $400 \times$; scale bars, $75 \mu \mathrm{m}$.

\subsection{In Vivo SPECT/CT in a Tourniquet-Induced I/R Mouse Model}

To confirm that [ $\left.{ }^{99 \mathrm{~m}} \mathrm{Tc}\right] \mathrm{Tc}-$ gluconate could be used as an $\mathrm{H}_{2} \mathrm{~S}$ imaging agent in vivo, [ $\left.{ }^{99 \mathrm{~m}} \mathrm{Tc}\right] \mathrm{Tc}-$ gluconate or [ $\left.{ }^{99 \mathrm{~m}} \mathrm{Tc}\right] \mathrm{Tc}-\mathrm{DTPA}$ was injected intravenously into a tourniquet-induced ischemia mouse model. The legs were imaged with SPECT/CT $1 \mathrm{~h}$ after the injection. The images showed markedly higher uptake of $\left[{ }^{99 \mathrm{~m}} \mathrm{Tc}\right] \mathrm{Tc}$-gluconate in the ischemic leg than that in the normoxic leg (Figure 6A). The standard uptake value (SUVmean) of the ischemic limb was $0.39 \pm 0.03$, while that of the normal limb was $0.07 \pm 0.01$. $\left.{ }^{99 \mathrm{~m}} \mathrm{Tc}\right] \mathrm{Tc}-$ DTPA showed slightly increased uptake in the ischemic leg than that in the normal leg

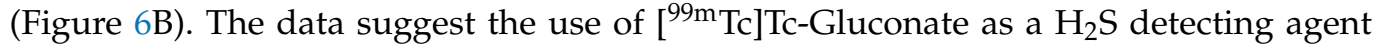
in vivo.
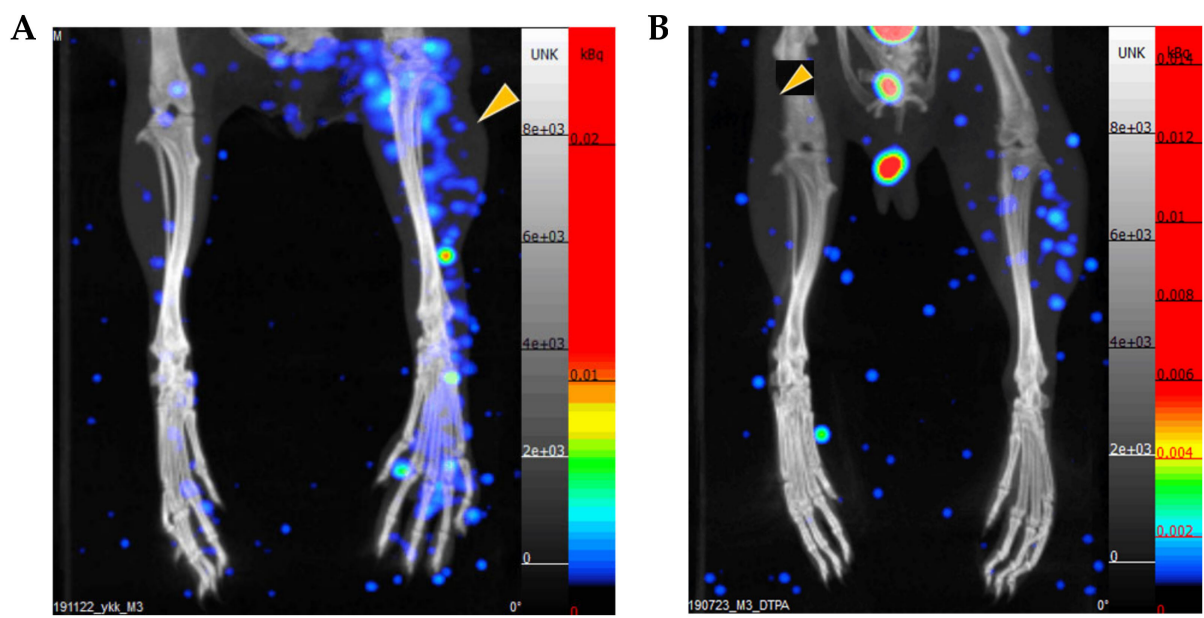

Figure 5. Cont. 


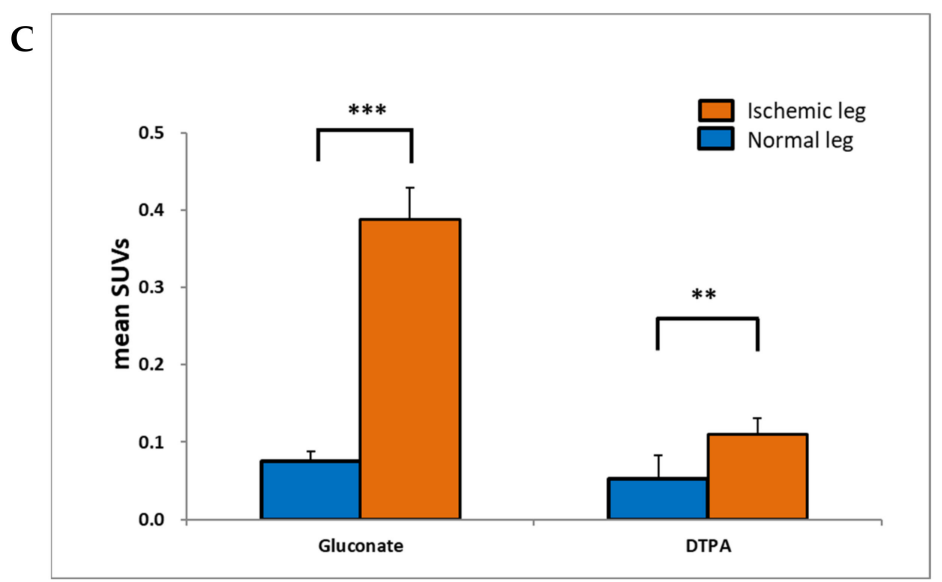

Figure 6. $\left[{ }^{99 \mathrm{~m}} \mathrm{Tc}\right] \mathrm{Tc}-$ Gluconate and [ $\left.{ }^{99 \mathrm{~m}} \mathrm{Tc}\right] \mathrm{Tc}-\mathrm{DTPA}$ imaging of an ischemia reperfusion mouse model. BALB/c mice received $3 \mathrm{~h}$ of tourniquet-induced ischemia modeling after $3 \mathrm{~h}$ of reperfusion (yellow triangle). Thereafter, $12 \mathrm{MBq}$ of (A) $\left[{ }^{99} \mathrm{~m} \mathrm{Tc}\right] \mathrm{Tc}$-gluconate or $(\mathbf{B})\left[{ }^{99 \mathrm{~m}} \mathrm{Tc}\right] \mathrm{Tc}-\mathrm{DTPA}$ was intravenously injected via tail vein. After $1 \mathrm{~h}$, legs were imaged by SPECT/CT. (C) Average standard uptake value (SUV) representing uptake in both normal and ischemic limbs. Statistical significance was determined using an unpaired Student's $t$-test. ${ }^{* *} p<0.05,{ }^{* * *} p<0.01$.

\section{Discussion}

Hydrogen sulfide $\left(\mathrm{H}_{2} \mathrm{~S}\right)$ has been known as a toxic molecule in biological systems for centuries. Recent studies have elucidated potential regulatory functions of $\mathrm{H}_{2} \mathrm{~S}$, which are similar to those of other gasotransmitters such as nitric oxide and carbon monoxide. When hypoxic conditions are induced, $\mathrm{H}_{2} \mathrm{~S}$ production increases via changes in the partial pressure of oxygen [18]. Since hypoxia is a common characteristic of solid tumors, it is necessary to detect and image endogenously produced $\mathrm{H}_{2} \mathrm{~S}$ under hypoxic conditions.

After injecting an $\mathrm{H}_{2} \mathrm{~S}$ detection probe (HSip-1), higher fluorescence intensity was observed in the ischemic-reperfusion injury legs compared to that in normal legs at every time point except at $24 \mathrm{~h}$ of reperfusion, thereby demonstrating that $\mathrm{H}_{2} \mathrm{~S}$ formation increased after $3 \mathrm{~h}$ of reperfusion. A previous study measured muscle blood flow by placing a transonic flow probe in the gastrocnemius muscles connected to a laser Doppler blood flowmeter. Blood flow to the gastrocnemius muscle was measured during the ischemiareperfusion for $3 \mathrm{~h}$ of ischemia and $4 \mathrm{~h}$ of reperfusion. When a tourniquet was applied to the limb, blood flow decreased to $2 \%$ of the baseline level and remained at the same level for $3 \mathrm{~h}$ of ischemia. When the limb was released, the blood flow rapidly increased to approximately $50 \%$ of the baseline level and declined to a steady state of $30 \%$ of the baseline level [19]. The results demonstrated that the fluorescence probe could not reach the gastrocnemius muscle after $1 \mathrm{~h}$ of reperfusion, as the blood vessels were clogged due to application of the tourniquet. Further measurements of blood flow during SPECT/CT imaging is warranted to elucidate the effects of reperfusion on probe movement through the limbs. Although no exact mechanisms for the formation of $\mathrm{H}_{2} \mathrm{~S}$ during reperfusion have been proposed thus far, in the present study, blood flow was consistent during the reperfusion time, and formation of $\mathrm{H}_{2} \mathrm{~S}$ increased at $3 \mathrm{~h}$ of reperfusion. In the present study, the fluorescence intensity in vivo imaging showed that $\mathrm{H}_{2} \mathrm{~S}$ was produced under hypoxic conditions and could be detected using fluorescence probes in vivo. We also used radionuclides for detecting $\mathrm{H}_{2} \mathrm{~S}$. In the present study, a technetium-99m $\left({ }^{99 \mathrm{~m}} \mathrm{Tc}\right)$-labeled agent was used because it is frequently used in radiology departments, is easy to access, and can be generated inexpensively. There are several advantages of using ${ }^{99 \mathrm{~m}} \mathrm{Tc}$, such as its rapid diagnosis and $6 \mathrm{~h}$ half-life, which implies that the radioisotopes decay quickly, and cause relatively less damage and no side effects [20].

Gluconic acid was successfully labeled with ${ }^{99 \mathrm{~m}} \mathrm{Tc}$ (Figure 4), and $\left[{ }^{99 \mathrm{~m}} \mathrm{Tc}\right] \mathrm{Tc}-$ gluconate formed with NaHS. In a previous study by our group, $\left[{ }^{99 \mathrm{~m}} \mathrm{Tc}\right] \mathrm{Tc}$-gluconate formed the highest percentage of insoluble fraction, which was not identical to $\mathrm{Tc}_{2} \mathrm{~S}_{7}$ [17]. How- 
ever, identification of the chemical structure of the insoluble fraction remains challenging. One possible reason for the formation of the insoluble fraction is the formation of insoluble polydisulfide $\left[\mathrm{Tc}_{3}\left(\mu^{3}-\mathrm{S}\right)\left(\mathrm{S}_{2}\right)_{3}\left(\mathrm{~S}_{2}\right)_{3 / 3}\right]_{n}$ by the trimerization of insoluble sulfide $\mathrm{Tc}(\mathrm{IV}) \mathrm{S}_{2}$ [21]. The chemical structure of [ $\left.{ }^{99 \mathrm{~m}} \mathrm{Tc}\right] \mathrm{Tc}$-gluconate is two gluconate molecules forming a complex with $\mathrm{Tc}(\mathrm{V}) \mathrm{O}$. The complex contains a $\mathrm{Tc}=\mathrm{O}$ core and two gluconate ligands (oxobis(gluconto)technetate(V) anion (net charge: -1 ) in aqueous solution) [22]. In our previous study, we determined the chemical structure of [ $\left.{ }^{99 \mathrm{~m}} \mathrm{Tc}\right] \mathrm{Tc}-g l u c o h e p t o n a t e$, and because of the molecular similarity of glucoheptonate and gluconate, $\left[{ }^{99 \mathrm{~m}} \mathrm{Tc}\right] \mathrm{Tc}$-gluconate should demonstrate a similar structure. If this structure is correct for $\left[{ }^{99 \mathrm{~m}} \mathrm{Tc}\right] \mathrm{Tc}$-gluconate, in the presence of $\mathrm{H}_{2} \mathrm{~S}, \mathrm{Tc}(\mathrm{V})$ can be reduced to $\mathrm{Tc}(\mathrm{IV})$ and precipitate, which will ensure feasibility of imaging. Another possibility is that ${ }^{99} \mathrm{~m}$ Tc can be fixed by transchelation with the sulfhydryl groups of proteins $[23,24]$. Further studies are warranted to identify the chemical structure of the insoluble fraction, and to determine the mechanisms of its formation.

Multiple studies have shown that $\left[{ }^{99 \mathrm{~m}} \mathrm{Tc}\right] \mathrm{Tc}-$ gluconate can be used for cancer, inflammation, and cerebral and myocardial ischemia imaging; however, the mechanism for its uptake has not been elucidated thus far. In the present study, [ $\left.{ }^{99 \mathrm{~m}} \mathrm{Tc}\right] \mathrm{Tc}$-gluconate uptake increased when hydrogen sulfide was produced under hypoxic conditions. This is possibly due to the formation of an insoluble fraction, thereby enabling imaging of $\mathrm{H}_{2} \mathrm{~S}$.

An additional benefit of using [ $\left.{ }^{99 \mathrm{~m}} \mathrm{Tc}\right] \mathrm{Tc}$-gluconate as a $\mathrm{H}_{2} \mathrm{~S}$ imaging agent compared to fluorescence imaging probes is that $\left[{ }^{99 \mathrm{~m}} \mathrm{Tc}\right] \mathrm{Tc}$-gluconate is already approved as a radiopharmaceutical, and has already been used in some countries. The application of [ $\left.{ }^{99} \mathrm{~m} \mathrm{Tc}\right] \mathrm{Tc}$-gluconate in a clinical setting for $\mathrm{H}_{2} \mathrm{~S}$ detection should therefore be approved faster than that for fluorescence probes. Ultimately, a test for $\mathrm{H}_{2} \mathrm{~S}$ is warranted in the clinical setting and our findings support the use of $\left[{ }^{99 \mathrm{~m}} \mathrm{Tc}\right] \mathrm{Tc}$-gluconate, both in vivo and in vitro.

\section{Materials and Methods}

\subsection{Solvents and Chemicals}

BCA Protein Assay Kit was purchased from Pierce Co (Rockford, IL, U.S.A.). All chemicals, reagents and solvents used were of analytical grade, and were purchased from Sigma Aldrich and TCI (Tokyo, Japan). ${ }^{99 \mathrm{~m}} \mathrm{Tc}$ was obtained from a ${ }^{99} \mathrm{Mo} /{ }^{99 \mathrm{~m}} \mathrm{Tc}-$ generator purchased from Sam Young Unitech Co. (Seoul, Korea). Instant thin-layer chromatography (ITLC) plates were purchased from Aglient Technologies (Santa Clara, CA, USA). The BioScan AR-2000 scanner (Bioscan Co., Wilmington, MA, USA) was used for ITLC plate scanning. SPECT/CT animal images were acquired using NanoSPECT/CT ${ }^{\text {Plus }}$ (Mediso, Budapest, Hungary) and analyzed with the InVivoScope program.

\section{2. ${ }^{99 m}$ Tc-Labeling of Gluconate and DTPA}

Distilled water purged with $\mathrm{N}_{2}$ gas was used for the labeling experiment. For the [ $\left.{ }^{99 \mathrm{~m}} \mathrm{Tc}\right] \mathrm{Tc}-$ gluconate labeling, $100 \mu \mathrm{L}$ of $0.3 \mathrm{M} \mathrm{D}$-gluconic acid sodium salt was prepared and added to $10 \mu \mathrm{L}$ of sodium ascorbic acid $(25 \mathrm{mg} / \mathrm{mL})$ and $50 \mu \mathrm{L}$ of $\mathrm{SnCl}_{2} 2 \mathrm{H}_{2} \mathrm{O}(1 \mathrm{mg} / \mathrm{mL}$ in $0.05 \mathrm{M} \mathrm{HCl})$, and mixed by vortexing. Approximately $370 \mathrm{MBq}(140 \mu \mathrm{L})$ of $\left[{ }^{99 \mathrm{~m}} \mathrm{Tc}^{\mathrm{N}} \mathrm{NaTcO}_{4}\right.$ eluted in normal saline obtained from the generator was added to the mixture at room temperature for $20 \mathrm{~min}(\mathrm{pH} 4.5)$.

Radiochemical quality control testing of [ $\left.{ }^{99 \mathrm{~m}} \mathrm{Tc}\right] \mathrm{Tc}$-gluconate using two instant thinlayer chromatography strips was performed via radio TLC. A drop of the labeled mixture was placed near the bottom of each ITLC strip and then placed in acetone or saline. As the solvent migrates upward, soluble radiochemical species are carried upward along with the solvent, while insoluble compounds remain at the origin. The radioactivity at each location on the strip was measured using a radio TLC scanner (Bioscan Co., WY, USA). When the mixture was eluted with acetone, reduced-hydrolyzed ${ }^{99 \mathrm{~m}} \mathrm{Tc}$ impurity and ${ }^{99 \mathrm{~m}} \mathrm{Tc}-$ labeled gluconate remained at the origin and unlabeled free ${ }^{99 \mathrm{~m}} \mathrm{Tc}$ moved upward to the solvent 
front. In contrast, when the mixture was eluted with saline, only reduced-hydrolyzed ${ }^{99 \mathrm{~m}} \mathrm{Tc}$ remained at the origin and [ $\left.{ }^{99 \mathrm{~m}} \mathrm{Tc}\right] \mathrm{Tc}$-gluconate moved to the solvent front.

For the $\left[{ }^{99 \mathrm{~m}} \mathrm{Tc}\right] \mathrm{Tc}-\mathrm{DTPA}$ labeling, a DTPA kit vial (Mallinckrodt, The Netherlands) was obtained from Seoul National University Hospital. Four milliliters of freshly eluted $\left[{ }^{99 \mathrm{~m}} \mathrm{Tc}\right] \mathrm{NaTcO}_{4}(400 \mathrm{MBq})$ obtained from the generator was added to the DTPA kit. Further, the labeled product was analyzed by ITLC and eluted with acetone or saline solution. Similarly, when it was eluted with acetone, labeled [ $\left.{ }^{99 \mathrm{~m}} \mathrm{Tc}\right] \mathrm{Tc}-\mathrm{DTPA}$ remained at the origin, while labeled [ $\left.{ }^{99 m} \mathrm{Tc}\right] \mathrm{Tc}-\mathrm{DTPA}$ moved to the solvent front when it was eluted with saline.

\subsection{Formation of Insoluble Fraction in the Presence of $\mathrm{H}_{2} \mathrm{~S}$}

One hundred-microliter samples of $\left[{ }^{99 \mathrm{~m}} \mathrm{Tc}\right] \mathrm{Tc}$-gluconate and $\left[{ }^{99 \mathrm{~m}} \mathrm{Tc}\right] \mathrm{Tc}-\mathrm{DTPA}$ were mixed with one hundred microliter of $0.2 \mathrm{mM} \mathrm{NaHS}$ in $0.2 \mathrm{M}$ sodium phosphate buffer ( $\mathrm{pH}$ 7.4). The mixtures were vortexed and incubated at $37^{\circ} \mathrm{C}$ for $10 \mathrm{~min}$, spotted onto ITLC plates, and eluted with saline. The ITLC plates were scanned using the Bio-Scan AR-2000. The insoluble fraction was analyzed by calculating the percentage of remaining radioactivity at the origin.

\subsection{Cell Culture}

CT26 (colon carcinoma cell line) cells were grown in the DMEM medium (Gibco, Grand Island, NY, USA) containing 10\% $(v / v)$ fetal bovine serum (Gibco, Grand Island, NY, USA) and $1 \%$ penicillin/streptomycin (Invitrogen, Grand Island, NY, USA). Cells were incubated at $37^{\circ} \mathrm{C}$ in a humidified incubator under a $5 \% \mathrm{CO}_{2}$ atmosphere.

\subsection{In Vitro Hypoxic Cell Culture Uptake of ${ }^{99 m}$ Tc-Gluconate}

CT26 cells were purchased from the Korean Cell Line Bank, cultured in the DMEM medium (High glucose, Gibco, Grand Island, NY, USA), and incubated at $37^{\circ} \mathrm{C}$ and $5 \%$ $\mathrm{CO}_{2}$ in a humidified incubator.

Cells were cultured under hypoxic conditions $\left(95 \% \mathrm{~N}_{2}\right.$ and $\left.5 \% \mathrm{CO}_{2}\right)$ and normoxic conditions $\left(95 \%\right.$ air and $\left.5 \% \mathrm{CO}_{2}\right)$ for measurement of [ [99m Tc]Tc-gluconate and $\left[{ }^{99 \mathrm{~m}} \mathrm{Tc}\right] \mathrm{Tc}-$ DTPA uptake. A suspension of $5 \times 10^{6}$ cells $/ \mathrm{mL}$ was produced in $\mathrm{N}_{2}$-purged media in sterile glass vials. Cells were incubated for $4 \mathrm{~h}$ under hypoxic and normoxic conditions. $\left[{ }^{99 \mathrm{~m}} \mathrm{Tc}\right] \mathrm{Tc}$-gluconate was diluted in a serum-free, $\mathrm{N}_{2}$-purged DMEM medium and $1 \mathrm{~mL}$ was added into vials. The vials were incubated in a humidified incubator at $37^{\circ} \mathrm{C}$ and $5 \% \mathrm{CO}_{2}$. At $30 \mathrm{~min}, 1 \mathrm{~h}$, and $2 \mathrm{~h}, 200 \mu \mathrm{L}$ of each suspension was collected into a $5 \mathrm{~mL}$ test tube. The cells were washed and centrifuged three times with cold Hank's balanced salt solution (HBSS), lysed in $0.2 \mathrm{~mL}$ of $1 \%$ SDS, and transferred into new $5 \mathrm{~mL}$ test tubes. The radioactivity of the cells was determined using a $\gamma$-counter. A BCA protein assay was performed the next day to determine total cell protein, according to the manufacturer's instructions.

\subsection{Ischemia-Reperfusion Mouse Modeling for In Vivo Imaging}

Tourniquet-induced ischemia-reperfusion was performed according to a previously reported method $[25,26]$. Mice were anesthetized with an anesthetic cocktail consisting of $0.1 \mathrm{mg} / \mathrm{g}$ alfaxalone and $0.01 \mathrm{mg} / \mathrm{g}$ xylazine, administered via intraperitoneal injection ( $0.005 \mathrm{~mL} / \mathrm{g}$ body weight).

Anesthesia was maintained throughout the experiments with an additional anesthetic cocktail $(0.05 \mathrm{~mL})$ as per requirements. Under anesthesia, mouse fur was completely removed from both hind limbs using an electric shaver and hair removal cream. The animals were restrained on a heating pad to maintain their body temperature at $37^{\circ} \mathrm{C}$.

Unilateral hind limb ischemia was induced by placing an orthodontic rubber band at the hip joint. After $3 \mathrm{~h}$ of ischemia, the orthodontic rubber band was released, and reperfusion was performed. 
4.7. In Vivo Detection of Endogenous $\mathrm{H}_{2} \mathrm{~S}$ by Fluorescence and SPECT/CT Imaging in a Mouse Model of Ischemia

To detect endogenously produced $\mathrm{H}_{2} \mathrm{~S}$ in the ischemic hindlimb, $100 \mu \mathrm{L}$ of HSip-1 $(200 \mu \mathrm{M})$ was intravenously injected after $0,1,3,12$, and $24 \mathrm{~h}$ of reperfusion. After $1 \mathrm{~h}$ of circulation, the mice were sacrificed, and the fluorescence signal intensities of the left and right limbs were measured. Fluorescence signals were measured using the Lumina II fluorometer (Perkin Elmer, Waltham, MA, USA). Fluorescence images were acquired with an exposure time of $20 \mathrm{~s}$, medium binning, $2 \mathrm{f} /$ stop, and an open filter. Data were analyzed using the Living Image software (version 2.5)

For SPECT/CT imaging, after $3 \mathrm{~h}$ of reperfusion, $12.5 \mathrm{MBq}\left[{ }^{99 \mathrm{~m}} \mathrm{Tc}\right] \mathrm{Tc}$-gluconate or 12.7 MBq [ ${ }^{99 m}$ Tc]Tc-DTPA in $100 \mu \mathrm{L}$ saline was intravenously injected. Only the lower limb was imaged with SPECT/CT by covering the upper limb with a $2 \mathrm{~mm}$ thick lead plate.

The scanning parameters for the whole-body imaging modality used a $\gamma$-ray energy window of $140 \mathrm{keV} \pm 10 \%$, a matrix size of $256 \times 256$, an acquisition time of 5 s per angular step of $18^{\circ}$, and a reconstruction algorithm of ordered subset expectation maximization with 9 iterations. For integrated $\mathrm{CT}$, a tube voltage of $45 \mathrm{kVp}$, an exposure time of $1.5 \mathrm{~s}$ per projection, and a reconstruction algorithm of cone-beam filtered back-projection was used. The SPECT/CT images were represented using the same scale conditions in InVivoScope on the nanoScan-SPECT/CT.

\subsection{Immunofluorescence Staining of Hindlimb Sections}

A two-hundred-microliter volume of 10 mM EF5 (hypoxia marker, \#CS222743, Millipore) was injected with HSip-1 ( $\mathrm{H}_{2} \mathrm{~S}$ marker, SB21, Dojindo Molecular Tech.). Both the ischemic and normal hind limbs were extracted immediately after analysis on the Lumina II fluorometer (Perkin Elmer, Waltham, MA, USA). Limbs were embedded in optimal cutting temperature (OCT) compound (Leicabiosystems, Richmond, IL, USA), snap-frozen, sectioned at $8 \mu \mathrm{m}$ thickness using a cryostat, and placed on slides. Sections were dried for $30 \mathrm{~min}$ at room temperature, fixed with acetone at $-20{ }^{\circ} \mathrm{C}$ for $10 \mathrm{~min}$, and then allowed to dry for $30 \mathrm{~min}$ at room temperature. Fixed slides were washed three times with PBS for $5 \mathrm{~min}$. After washing, all sections were marked with a PAP pen (hydrophobic pen), and blocking solution was added. The slides were placed in a staining tray containing a small amount of water covered with a lid overnight at $4{ }^{\circ} \mathrm{C}$. After the blocking solution was removed, all slides were washed and rinsed with $1 \times \mathrm{ttPBS}(1 \times$ PBS with $0.3 \%$ Tween 20 , and $2 \mathrm{mM}$ sodium azide).

Staining solution (Cy3-conjugated anti-EF5 $(75 \mu \mathrm{g} / \mathrm{mL}), 100 \mu \mathrm{L})$ was added to slides for $6 \mathrm{~h}$ in a tin-foil-covered staining tray with a lid at $4{ }^{\circ} \mathrm{C}$. After staining, all slides were washed three times with cold PBS for $40 \mathrm{~min}$ in the dark. Mounting was performed with the ProlongTM Gold antifade reagent with DAPI (Invitrogen, USA). Fluorescence images were acquired the next day using a confocal laser scanning microscope (Leica TCS SP8, Wetzlar, Hesse, Germany).

\subsection{Confocal Imaging}

Confocal imaging was used to analyze the fluorescence signal in the samples. After performing immunofluorescence staining, samples were washed with PBS three times, and the samples were mounted with the ProLong ${ }^{\mathrm{TM}}$ Gold antifade reagent with DAPI (Invitrogen, Grand Island, NY, U.S.A) and covered with a cover slide. The confocal imaging samples were stored at $4{ }^{\circ} \mathrm{C}$ and imaged the next day. Fluorescence signals were detected using a confocal laser scanning microscope (Leica TCS SP8m Wetzlar, Hesse, Germany) in the specific range of wavelength (DAPI; 401-480, FITC; 495-519 Cy3; 550-570). Fluorescence intensities were analyzed using the LAS X system (Leica Microsystems, Wetzlar, Germany). 


\subsection{Statistical Analysis}

Quantitative data are expressed as mean $\pm \mathrm{SD}$. Mean values were compared using the Student's $t$-test in Excel (Microsoft, Redmond, WA, U.S.A.) or GraphPad Prism (GraphPad Software, Inc., San Diego, CA, USA).

\section{Conclusions}

Endogenously produced $\mathrm{H}_{2} \mathrm{~S}$ in hypoxic tissue can be imaged using [ $\left.{ }^{99 \mathrm{~m}} \mathrm{Tc}\right] \mathrm{Tc}$-gluconate both in vivo and in vitro.

Author Contributions: Conceptualization, J.-M.J.; methodology, J.-M.J., Y.K., J.-Y.P., Y.-J.K.; investigation, Y.-S.L.; writing-Original draft preparation, Y.K.; supervision, J.-M.J.; project administration, J.-M.J. and Y.-S.L.; funding acquisition, J.-M.J. All authors have read and agreed to the published version of the manuscript.

Funding: This research was funded by the Technology Innovation Program funded by the Ministry of Trade, Industry and Energy (20001235) and Ministry of Health and Welfare (HI15C-3093-010017).

Institutional Review Board Statement: All animal studies were approved by the Institutional Animal Care and Use Committee of Seoul National University Hospital (SNUH-IACUC) (19-0210S1A1).

Data Availability Statement: Data sharing not applicable.

Acknowledgments: We appreciate the administrative support of Young-Sil Moon and the English revision service of Editage.

Conflicts of Interest: The authors declare no conflict of interest.

\section{References}

1. Wang, R. Two's company, three's a crowd: Can $\mathrm{H}_{2}$ S be the third endogenous gaseous transmitter? FASEB J. 2002, 16, 1792-1798. [CrossRef]

2. Yang, G.D.; Wu, L.Y.; Jiang, B.; Yang, W.; Qi, J.S.; Cao, K. $\mathrm{H}_{2} \mathrm{~S}$ as a physiologic vasorelaxant: Hypertension in mice with deletion of cystathionine gamma-lyase. Science 2008, 322, 587-590. [CrossRef]

3. Mir, J.M.; Maurya, R.C. A gentle introduction to gasotransmitters with special reference to nitric oxide: Biological and chemical implications. Rev. Inorg. Chem. 2018, 38, 193-220. [CrossRef]

4. Olson, K.R.; Straub, K.D. The role of hydrogen sulfide in evolution and the evolution of hydrogen sulfide in metabolism and signaling. Physiology 2016, 31, 60-72. [CrossRef]

5. Barton, L.L.; Fardeau, M.L.; Fauque, G.D. Hydrogen sulfide: A toxic gas produced by dissimilatory sulfate and sulfur reduction and consumed by microbial oxidation. Met. Ions Life Sci. 2014, 14, 237-277.

6. Ishigami, M.; Hiraki, K.; Umemura, K.; Ogasawara, Y.; Ishii, K.; Kimura, H. A source of hydrogen sulfide and a mechanism of its release in the brain. Antioxid. Redox Signal. 2009, 11, 205-214. [CrossRef]

7. Wang, R. Physiological implications of hydrogen sulfide: Awhiff exploration that blossomed. Physiol. Rev. 2012, 92, 791-896. [CrossRef] [PubMed]

8. Cooper, C.E.; Brown, G.C. The inhibition of mitochondrial cytochrome oxidase by the gases carbon monoxide, nitric oxide, hydrogen cyanide and hydrogen sulfide: Chemical mechanism and physiological significance. J. Bioenerg. Biomembr. 2008, 40, 533-539. [CrossRef] [PubMed]

9. Pan, L.L.; Liu, X.H.; Gong, Q.H.; Yang, H.B.; Zhu, Y.Z. Role of cystathionine gamma-lyase/hydrogen sulfide pathway in cardiovascular disease: A novel therapeutic strategy? Antioxid. Redox Signal. 2012, 17, 106-118. [CrossRef] [PubMed]

10. Lippert, A.R.; New, E.J.; Chang, C.J. Reaction-Based fluorescent probes for selective imaging of hydrogen sulfide in living cells. J. Am. Chem. Soc. 2011, 133, 10078-10080. [CrossRef] [PubMed]

11. Kanagy, N.L.; Szabo, C.; Papapetropoulos, A. Vascular biology of hydrogen sulfide. Am. J. Physiol. Cell Physiol. 2017, 312, 537-549. [CrossRef] [PubMed]

12. Wang, R. Signaling pathways for the vascular effects of hydrogen sulfide. Curr. Opin. Nephrol. Hypertens. 2011, $20,107-112$. [CrossRef] [PubMed]

13. Hope-Ross, M.; Yannuzzi, L.A.; Gragoudas, E.S.; Guyer, D.R.; Slakter, J.S.; Sorenson, J.A.; Krupsky, S.; Orlock, D.A.; Puliafito, C.A. Adverse reactions due to indocyanine green. Ophthalmology 1994, 101, 529-533. [CrossRef]

14. Boswell, C.A.; Brechbiel, M.W. Development of radioimmunotherapeutic and diagnostic antibodies: An inside-out view. Nucl. Med. Biol. 2007, 34, 757. [CrossRef]

15. Yaoita, H.; Uehara, T.; Brownell, A.L.; Rabito, C.A.; Ahmad, M.; Khaw, B.A.; Fischman, A.J.; Strauss, H.W. Localization of technetium-99m-glucarate in zones of acute cerebral injury. J. Nucl. Med. 1991, 32, 272-278. 
16. Sarkar, S.; Ha, Y.S.; Soni, N.; An, G.I.; Lee, W.; Kim, M.H.; Huynh, P.T.; Ahn, H.; Bhatt, N.; Lee, Y.J.; et al. Immobilization of the gas signaling molecule $\mathrm{H}_{2} \mathrm{~S}$ by radioisotopes: Detection, quantification, and in vivo imaging. Angew. Chem. Int. Ed. 2016, 55, 9365-9370. [CrossRef]

17. Park, J.Y.; Kim, Y.J.; Lee, J.Y.; Lee, Y.-S.; Jeong, J.M. Imaging of the third gasotransmitter hydrogen sulfide using $99 \mathrm{mTc}$-labeled alpha-hydroxy acids. Nucl. Med. Biol. 2019, 28, 76-77. [CrossRef]

18. Kim, J.Y.; Sarkar, S.; Bobba, K.N.; Huynh, P.T.; Bhise, A.; Yoo, J.S. Development of dansyl based copper(II) complex to detect hydrogen sulfide in hypoxia. Org. Biomol. Chem. 2019, 17, 7088-7094. [CrossRef]

19. Tran, T.P.; Tu, H.; Pipinos, I.I.; Muelleman, R.L.; Albadawic, H.; Li, Y.L. Tourniquet-induced acute ischemia-Reperfusion injury in mouse skeletal muscles: Involvement of superoxide. Eur. J. Pharmacol. 2011, 650, 328-334. [CrossRef]

20. Vucina, J. Technetium-99m production for use in nuclear medicine. Med. Pregl. 2000, 53, 631-634.

21. German, K.E.; Shiryaev, A.A.; Safonov, A.V.; Obruchnikova, Y.A.; Ilin, V.A.; Tregubova, V.E. Technetium sulfide-Formation kinetics, structure and particle speciation. Radiochim. Acta 2015, 103, 199-203. [CrossRef]

22. De Kieviet, W. Technetium radiopharmaceuticals: Chemical characterization and tissue distribution of Tc-glucoheptonate using Tc-99m and carrier Tc-99. J. Nucl. Med. 1981, 22, 703-709. [PubMed]

23. Jeong, J.M.; Hong, M.K.; Lee, J.; Son, M.; So, Y.; Lee, D.S. ${ }^{99 \mathrm{~m}}{ }^{\mathrm{Tc}}-\mathrm{neomannosyl} \mathrm{human} \mathrm{serum} \mathrm{albumin} \mathrm{(99mTc-MSA)} \mathrm{for} \mathrm{imaging}$ the hepatic asialoglycoprotein receptor. Bioconjug. Chem. 2004, 15, 850-855. [CrossRef] [PubMed]

24. Jeong, J.M.; Hong, M.K.; Kim, Y.J.; Lee, J.-T.; Kang, J.H.; Lee, D.S.; Chung, J.-K.; Lee, M.C. Development of 99mTc-neomannosyl human serum albumin (99mTc-MSA) as a novel receptor binding agent for sentinel lymph node imaging. Nucl. Med. Commun. 2004, 25, 1211-1217. [CrossRef]

25. Paradis, S.; Charles, A.L.; Meyer, A.; Lejay, A.; Scholey, J.W.; Chakfé, N.; Zoll, J.; Geny, B. Chronology of mitochondrial and cellular events during skeletal muscle ischemia-reperfusion. Am. J. Physiol. Cell Physiol. 2016, 310, 968-982. [CrossRef]

26. Bonheur, J.A.; Albadawi, H.; Patton, G.M.; Watkins, M.T. A noninvasive murine model of hind limb ischemia-reperfusion injury. J. Surg. Res. 2004, 116, 55-63. [CrossRef] 